Article

\title{
An Inter-Comparison of Techniques for Determining Velocities of Maritime Arctic Glaciers, Svalbard, Using Radarsat-2 Wide Fine Mode Data
}

\author{
Thomas Schellenberger ${ }^{1, *}$, Wesley Van Wychen ${ }^{2}$, Luke Copland ${ }^{2}$, Andreas Kääb ${ }^{1}$ and \\ Laurence Gray ${ }^{2}$ \\ 1 Department of Geosciences, University of Oslo, Oslo 0371, Norway; andreas.kaab@geo.uio.no \\ 2 Department of Geography, Environment and Geomatics, University of Ottawa, Ottawa, ON K1N 6N5, \\ Canada; wvanw046@uottawa.ca (W.V.W.); luke.copland@uottawa.ca (L.C.); laurence.gray@uottawa.ca (L.G.) \\ * Correspondence: thomas.schellenberger@geo.uio.no; Tel.: +47-2285-7869
}

Academic Editors: Frank Paul, Kate Briggs, Robert McNabb, Christopher Nuth, Jan Wuite, Zhong Lu, Richard Gloaguen and Prasad S. Thenkabail

Received: 20 July 2016; Accepted: 16 September 2016; Published: 21 September 2016

\begin{abstract}
Glacier dynamics play an important role in the mass balance of many glaciers, ice caps and ice sheets. In this study we exploit Radarsat-2 (RS-2) Wide Fine (WF) data to determine the surface speed of Svalbard glaciers in the winters of 2012/2013 and 2013/2014 using Synthetic Aperture RADAR (SAR) offset and speckle tracking. The RS-2 WF mode combines the advantages of the large spatial coverage of the Wide mode $(150 \times 150 \mathrm{~km})$ and the high pixel resolution $(9 \mathrm{~m})$ of the Fine mode and thus has a major potential for glacier velocity monitoring from space through offset and speckle tracking. Faster flowing glaciers $\left(1.95 \mathrm{~m} \cdot \mathrm{d}^{-1}-2.55 \mathrm{~m} \cdot \mathrm{d}^{-1}\right)$ that are studied in detail are Nathorstbreen, Kronebreen, Kongsbreen and Monacobreen. Using our Radarsat-2 WF dataset, we compare the performance of two SAR tracking algorithms, namely the GAMMA Remote Sensing Software and a custom written MATLAB script (GRAY method) that has primarily been used in the Canadian Arctic. Both algorithms provide comparable results, especially for the faster flowing glaciers and the termini of slower tidewater glaciers. A comparison of the WF data to RS-2 Ultrafine and Wide mode data reveals the superiority of RS-2 WF data over the Wide mode data.
\end{abstract}

Keywords: SAR offset and speckle tracking; glacier velocity; Radarsat-2 Wide Fine; Svalbard

\section{Introduction}

Monitoring the dynamics of glaciers has become increasingly important as concern about climate change increases. This is especially true for marine terminating glaciers, where measurements of ice motion can be combined with ice thickness information to determine frontal ablation rates, and hence the contribution of glaciers and ice sheets to global sea level rise. In light of this, in recent years there has been a concerted effort to map glacier dynamics at the regional scale for many of the glaciated regions of the world: Antarctica [1], the Greenland Ice Sheet [2,3], the majority of Alaskan glaciers [4,5], the Canadian High Arctic [6-8] and South America [9-11].

Glacier surface velocity is known for many glaciers on Svalbard (e.g., [12-21]), but none of these studies provide an overview of velocities across the entire archipelago. The first goal of this study is therefore to provide the first complete surface velocity map for all glaciers on Svalbard. This information is crucial for tasks such as estimating frontal ablation rates (iceberg calving), and to understand if they are changing over time.

Various methods have been used in the above mentioned studies to derive glacier motion using synthetic aperture radar (SAR) data and optical imagery, with the most prominent ones being image matching/offset and speckle tracking, coherence tracking and differential radar interferometry. 
A comprehensive overview of the SAR methods is given in [22,23], but to our knowledge there are only two previous studies that have compared different SAR offset and speckle tracking algorithms [23,24]. Therefore, the second aim of this study is to compare two correlation based matching techniques, namely the GAMMA Remote Sensing Software [25], widely used in the glaciological community, and a custom written MATLAB code, the GRAY method [26].

Offset tracking relies on reoccurring amplitude and/or phase patterns between two SAR images, such as from crevasses. An advantage of offset tracking compared to radar interferometry is that it provides two-dimensional displacement estimates in both the range and azimuth directions and it is more robust against slight changes to the glacier surface features caused by rain or snowfall, snow drift, melt or movement of the glacier itself, which destroys the phase coherence required for interferometry. This, however, comes typically at the cost of lower resolution and precision of the speed maps compared to interferometry, which makes offset tracking less suited for small displacements and small glaciers.

Speckle tracking is an offset tracking technique that relies on the coherence of the radar speckle pattern. Speckle is the modification of the intensity due to the interference of coherent waves coming from different scatterers within one pixel. Under a maritime climate, such as in Svalbard where melt and rain regularly change the properties of the surface, even in winter [27], the speckle pattern is typically not preserved over the 24 days of the repetition cycle of Radarsat-2 (RS-2). The same applies for radar interferometry or coherence tracking due to the temporal phase decorrelation. Speckle tracking techniques have also been used in other fields, such as the mapping of landslides [28] and monitoring of surface deformation in open pit mines [29].

This study is also the first to use the RS-2 Wide Fine (WF) mode data for glacier surface velocity monitoring in Svalbard. The WF mode was implemented only in 2011, four years after the launch of the satellite in 2007 [30]. It overcomes the shortcomings of the Wide mode (W) (pixel resolution: $13.5 \times 7.7 \mathrm{~m}$ with a nominal scene size of $150 \times 150 \mathrm{~km}$ ) and the Fine mode $(\mathrm{F})$ (nominal scene size: $50 \times 50 \mathrm{~km}$ at a pixel resolution of $5.2 \times 7.7 \mathrm{~m}$ ). Instead, it combines the advantage of both with a nominal scene size of $150 \times 150 \mathrm{~km}$ and a pixel resolution of $5.2 \times 7.7 \mathrm{~m}$. The third goal of our study is thus to review the performance of this mode against RS-2 Ultrafine mode (UF, pixel resolution: $1.6 \times 2.8 \mathrm{~m}$ ) and RS-2 W mode, as WF data have a slightly higher noise level compared to the W, the F and the UF modes [30]. For that purpose, we have acquired nearly simultaneous data using the three modes for fast-flowing Kronebreen during winter 2012/2013.

\section{Study Area-Svalbard}

The Svalbard archipelago is situated between $74^{\circ} \mathrm{N}$ and $81^{\circ} \mathrm{N}$, and $10^{\circ} \mathrm{E}$ and $35^{\circ} \mathrm{E}$. In total, 1668 glaciers covered $57 \%$ of the landmass $\left(33,775 \mathrm{~km}^{2}\right)$ in the late 2000s [31]. Depending on the definition of a tidewater glacier [31], 168-197 tidewater-terminating glaciers exist on Svalbard. They drain $68 \%$ of the glacierized terrain through a total glacier terminus width of about $740 \mathrm{~km} \mathrm{[31].}$

Temporal variability in glacier ice motion has previously been identified on Svalbard, which in most, but not all cases, has been attributed to surging. For example, Murray et al. [32] studied the surge of Monacobreen during the 1990s and found indications that the initiation and mechanisms of the glacier surge were distinct from those previously observed in Alaska (longer duration, thermally regulated in Svalbard). Sund et al. [20] found maximum velocities of $25 \mathrm{~m} \cdot \mathrm{d}^{-1}$ during the initiation of the Nathorstbreen glacier system surge. Dunse et al. [14] monitored the surge of Basin-3 on Austfonna and explained the multiannual speed-up by a hydro-thermodynamic feedback to summer melt. The resultant Basin-3 frontal ablation of $7.2 \pm 2.6 \mathrm{Gt} \cdot \mathrm{year}^{-1}$ represents as much as the combined flux from the rest of the archipelago $\left(6.75 \pm 1.7 \mathrm{~km}^{3} \cdot \mathrm{yesr}^{-1}\right)$ as estimated by Blaszczyk et al. [12].

\section{Radarsat-2 Wide Fine Data}

Radarsat-2 (RS-2) is a Canadian Synthetic Aperture Radar (SAR) satellite launched in 2007. It contains a C-Band sensor $(5.4 \mathrm{GHz})$ and can acquire images in a range of different modes. 
Each Stripmap and ScanSAR mode provides unique datasets where the user has to make a trade-off between pixel resolution and spatial coverage. The RS-2 Wide Fine (WF) beam is a single beam or Stripmap mode implemented only in 2011. It combines the advantage of the high pixel resolution of the Fine mode $(5.2 \times 7.7 \mathrm{~m}$ nominal resolution) with the large coverage of the Wide mode $(150 \times 150 \mathrm{~km}$; see also Table 1). The drawback, however, is a slightly higher noise level [30]. Our data are acquired in the F0W1 or F0W2 beam position and are linear co-polarized (HH) or dual co-and cross-polarized $(\mathrm{HH}+\mathrm{HV})$. Fourteen Radarsat-2 Wide Fine beam images covering nearly all the glaciated area of Svalbard were acquired in winters of 2012/2013 and 2013/2014 through the Canadian Space Agency's SOAR-E (Science and Operational Applications Research-Education) program (Figure 1, Table 2).

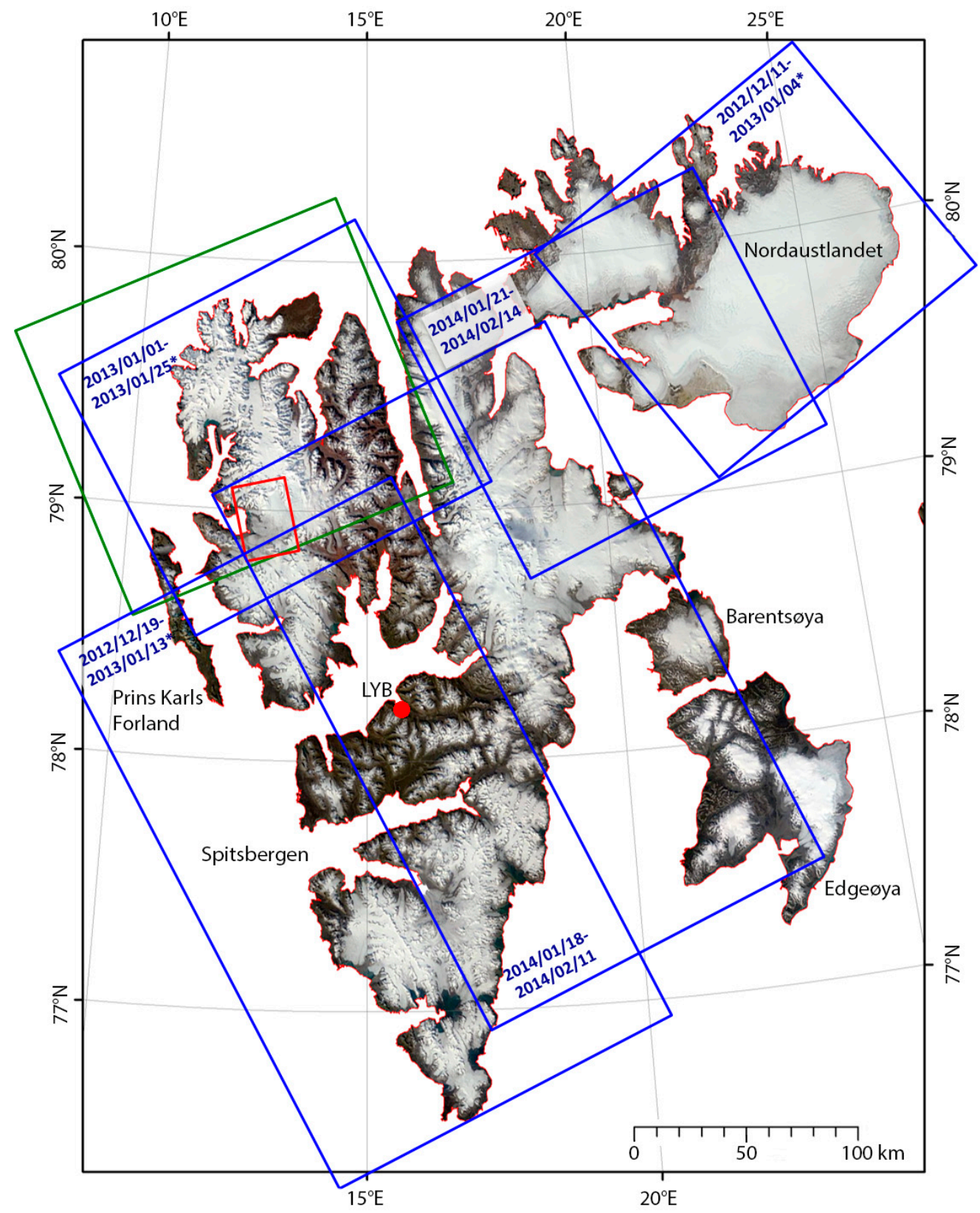

Figure 1. Image extents of Radarsat-2 image pairs utilized in this study (green outlines denote Radarsat-2 Wide imagery acquired 25 December 2012 and 18 January 2013; red outlines denote Radarsat-2 Ultrafine imagery acquired 3 January 2013 and 20 February 2013; blue outlines denote Radarsat-2 Wide Fine imagery with acquisition dates). Names of the main islands and the location of Longyearbyen (LYB) are also marked. Background image: MODIS Terra RGB composite. 
We also utilize RS-2 Ultrafine (UF) data acquired under the Norwegian/Canadian Radarsat agreement on 3 January 2013 and 20 February 2013 (2 repetition cycles) to estimate the speed of Kronebreen. The UF surface speed has a higher accuracy due to higher pixel resolution of the original intensity data. We also compare to coarser resolution RS-2 Wide (W) data acquired on 25 December 2012 and 18 January 2013.

Table 1. Radarsat-2 Beam modes used in this study with nominal resolution and scene size.

\begin{tabular}{ccc}
\hline Beam Mode & $\begin{array}{c}\text { Nominal Resolution (m) } \\
\text { (Range } \times \text { Azimuth) }\end{array}$ & $\begin{array}{c}\text { Nominal Scene Size (km) } \\
\text { (Range } \times \text { Azimuth) }\end{array}$ \\
\hline Ultra-Fine (UF) & $1.6 \times 2.8$ & $20 \times 20$ \\
Wide Fine (WF) & $5.2 \times 7.7$ & $150 \times 150$ \\
Wide (W) & $13.5 \times 7.7$ & $150 \times 150$ \\
Fine (F) & $5.2 \times 7.7$ & $50 \times 50$ \\
\hline
\end{tabular}

Table 2. Description of the dataset and processing parameters used in this study for different regions: mid-west (MW), east-northeast (ENE), mid-north (MN), south (S), southeast (SE), northeast (NE), northwest (NW) and Kronebreen.

\begin{tabular}{|c|c|c|c|c|c|c|}
\hline \multirow[t]{2}{*}{$\begin{array}{l}\text { Beam } \\
\text { Mode }\end{array}$} & \multirow[t]{2}{*}{ Beam } & \multirow[t]{2}{*}{ Region } & \multirow[t]{2}{*}{ Acquisition Dates } & \multicolumn{2}{|c|}{$\begin{array}{c}\text { Processing Parameters } \\
\text { Window Size/Step Size (Pixels) }\end{array}$} & \multirow[t]{2}{*}{$\begin{array}{c}\text { Resolution Speed }(\mathrm{m}) \\
\text { (Range } \times \text { Azimuth) }\end{array}$} \\
\hline & & & & GAMMA & GRAY & \\
\hline \multirow{7}{*}{ Wide Fine } & \multirow{5}{*}{ F0W01 } & MW & $\begin{array}{l}19 \text { December 2012- } \\
12 \text { January } 2013\end{array}$ & \multirow{5}{*}{$83 \times 152 / 10 \times 19$} & \multirow{5}{*}{$\begin{array}{c}83 \times 152 / \\
5 \times 10\end{array}$} & \multirow{5}{*}{$100 \times 100$} \\
\hline & & ENE & $\begin{array}{l}11 \text { December 2012- } \\
\text { 04 January } 2013\end{array}$ & & & \\
\hline & & $\mathrm{MN}$ & $\begin{array}{l}18 \text { January 2014- } \\
11 \text { February } 2014\end{array}$ & & & \\
\hline & & S & $\begin{array}{l}19 \text { December 2012- } \\
12 \text { January } 2013\end{array}$ & & & \\
\hline & & SE & $\begin{array}{l}18 \text { January 2014- } \\
11 \text { February } 2014\end{array}$ & & & \\
\hline & \multirow{2}{*}{ F0W02 } & NE & $\begin{array}{l}21 \text { January } 2014- \\
14 \text { February } 2014\end{array}$ & \multirow{2}{*}{$104 \times 161 / 13 \times 20$} & \multirow{2}{*}{$\begin{array}{l}83 \times 152 / \\
5 \times 10\end{array}$} & \multirow{2}{*}{$100 \times 100$} \\
\hline & & NW & $\begin{array}{l}\text { 01 January 2013- } \\
25 \text { January } 2013\end{array}$ & & & \\
\hline Ultrafine & U20 & Krone-breen & $\begin{array}{l}\text { 03 January 2013- } \\
20 \text { February } 2013\end{array}$ & $135 \times 130 / 27 \times 26$ & - & $50 \times 50$ \\
\hline Wide & W2 & NW & $\begin{array}{l}25 \text { December 2012- } \\
18 \text { January } 2013\end{array}$ & $40 \times 160 / 5 \times 20$ & - & $100 \times 100$ \\
\hline
\end{tabular}

\section{Methods}

\subsection{GAMMA Remote Sensing Offset and Speckle Tracking}

The offset and speckle tracking algorithm of the commercial software package GAMMA Remote Sensing, whose implementation is described in [25], has been widely used with different SAR sensors to extract glacier motion from repeat SAR images, e.g., in Svalbard with TerraSAR-X [14] and Radarsat data [19] as well as ALOS PALSAR in Alaska [4].

In this study, the workflow starts with the conversion of the two RS-2 single look complex (SLC) files into the GAMMA SLC format. Both files were then co-registered by an initial offset estimation from orbital parameters and in a second step by fitting of a polynomial function. Afterwards, local offsets were estimated and the orbital offsets were subtracted to compute glacier motion. The GAMMA matching algorithm is implemented in the frequency domain and the correlation is calculated by multiplying the reference and the search window of the same size. We used different matching window and step sizes depending on the resolution of the SLC data to achieve in all cases a search window of $\sim 800 \times 800 \mathrm{~m}$ and a resolution of the final velocity map of $100 \mathrm{~m}$ (Table 2). The results are then georeferenced using a smoothed version of the ASTER GDEM digital elevation model (DEM) [31]. 
Postprocessing steps included the manual filtering of mismatches (deleting of local abnormal values in magnitude/direction, identified by visual inspection) and interpolation of small voids using an inverse distance weighting algorithm in ArcMAP.

\subsection{GRAY Offset and Speckle Tracking}

The second tracking method used in this study is a custom written MATLAB offset and speckle tracking script [33]; hereafter referred to as the GRAY method, which has been utilized to derive glacier velocities for the Canadian High Arctic [6-8] and the Yukon/Alaska region [34]. The tracking process started with Radarsat-2 Single-Look Complex (SLC) data. To preserve bandwidth and image resolution, the speckle-tracking began by up-sampling the SLC data by a factor of two in both the range and azimuth directions (in the azimuth direction up-sampling takes into account the Doppler centroid frequency) and an initial coarse image-to-image registration took place [8]. User defined image chip sizes (detailed in Table 2) were then selected from the earlier (master) image and a two-dimensional search was undertaken to identify the matching image chip in the second (slave) image. The resulting normalized two-dimensional cross-correlation function was up-sampled and the peak was used to give the best estimates of the displacements in both the azimuth and range directions [8]. As a consequence of orbit cycles that do not perfectly repeat, there can be a stereo component in the slant range direction due to the perpendicular baseline [35], leading to a topography-dependent range displacement which does not represent surface displacement. To remove this topographic effect, a DEM (in this case the smoothed version of the ASTER GDEM of Svalbard) was used. Displacements are then calibrated to areas of zero motion (bedrock outcrops) in order to remove systematic biases that arise from inaccuracies in satellite baseline estimates or squint effects between image acquisitions [8]. Displacement results are standardized afterwards to annual displacement values (e.g., m·year ${ }^{-1}$ ) and are exported from MATLAB as a text file, which can be imported into a Geographic Information System.

Incorrect matches, or blunders, occur when the tracking algorithm finds a stronger correlation with an incorrect image chip rather than the "true" match. In order to identify and remove these mismatches, manual filtering (deleting of local abnormal values in magnitude/direction, identified by visual inspection) and verification of the velocity dataset were undertaken in ArcMAP on all velocity results. After all obviously incorrect matches were removed from the dataset, the point velocity dataset was interpolated to a $100 \mathrm{~m}$ grid spacing using an inverse distance weighting algorithm to produce a continuous raster surface of glacier velocities, comparable to the GAMMA output.

\subsection{Comparison of RS-2 Wide Fine Velocities to GPS Displacements on Kronebreen}

Four single frequency GPS receivers (L1 band, C/ A code only) [36] were mounted on Kronebreen at the time of the RS-2 Wide Fine acquisitions. Positions were acquired every three hours with a nominal accuracy of $1.6 \mathrm{~m}$ [36]. Here we compare the displacements from these four stations between 1 January 2013 and 25 January 2013 to the RS-2 WF velocity maps (Figure 2). The location of the GPSs on Kronebreen on 1 January 2013 were: GPS\#1: $78.903267^{\circ} \mathrm{N} 13.071833^{\circ} \mathrm{E}$; GPS\#2: $78.87645^{\circ} \mathrm{N}$ $12.59163^{\circ} \mathrm{E}$; GPS\#3: $78.887929^{\circ} \mathrm{N} 12.936602^{\circ} \mathrm{E}$; GPS\#4: $78.873024^{\circ} \mathrm{N} 12.797354^{\circ} \mathrm{E}$.

For the map derived with GAMMA we find a fit of the displacements of $\mathrm{d}_{\mathrm{GAMMA}}=0.91 \mathrm{~d}_{\mathrm{GPS}}+$ 1.46 and an $\mathrm{R}^{2}=1.00$. The fit for the GRAY map to the GPS is $\mathrm{d}_{\mathrm{GRAY}}=1.03 \mathrm{~d}_{\mathrm{GPS}}+0.28$ with a $\mathrm{R}^{2}=1.00$. 

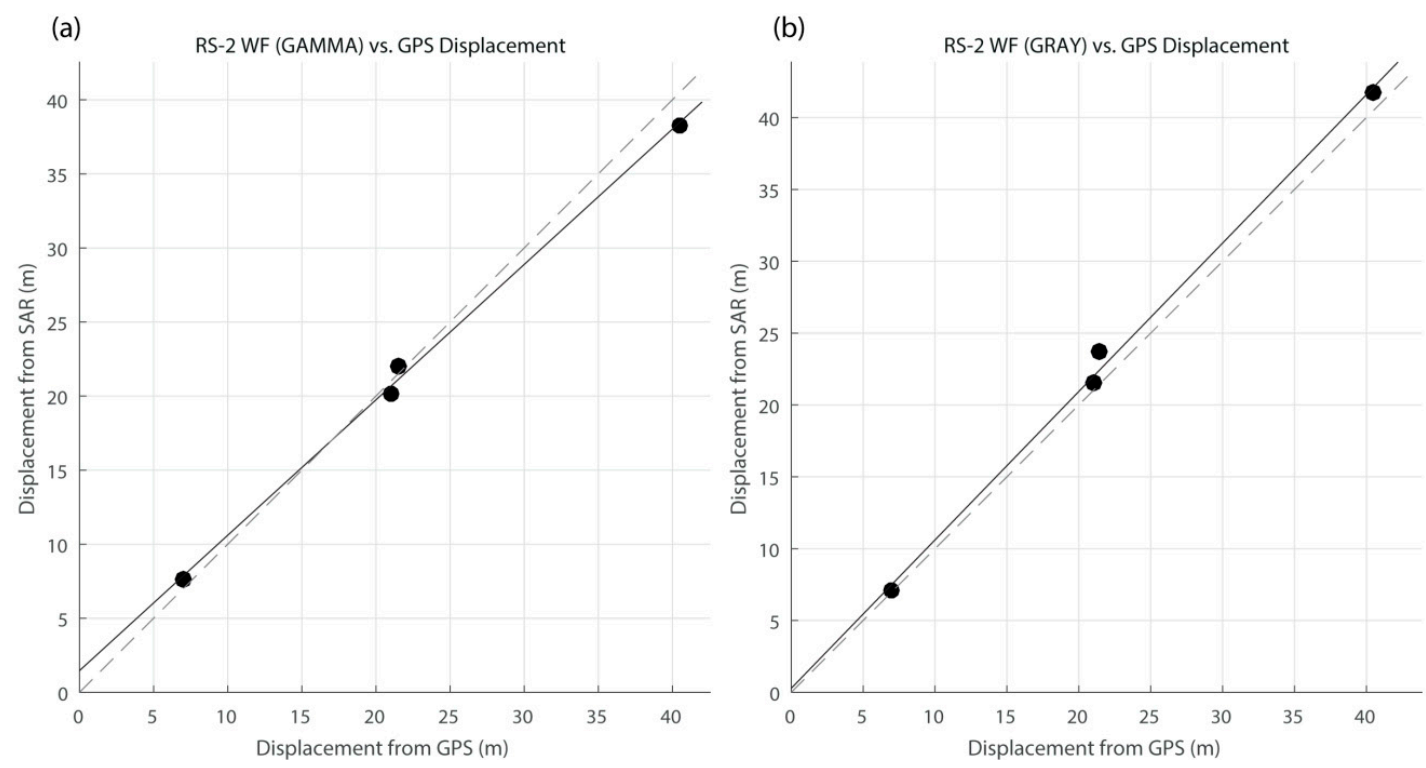

Figure 2. Comparison of displacements of Kronebreen from RS-2 Wide Fine data and GPS: (a) RS-2 Wide Fine (GAMMA) vs. GPS; and (b) RS-2 Wide Fine (GRAY) vs. GPS. Solid line: regression line. Dashed line: line of equality $(y=x)$. For GPS data see Schellenberger et al. [19], courtesy of J. Kohler (Norwegian Polar Institute) and C. Reijmer (Utrecht University).

\subsection{Accuracy of the Co-Registration}

A good method to assess the accuracy of the co-registration is to investigate apparent displacements on bedrock. We overlaid a point grid with one kilometer spacing on the velocity maps and extracted speeds at each grid point. From these values we then calculated the mean bedrock displacement for each scene. The highest accuracy and therefore the best co-registration with GAMMA was found for the north-western scene with a mean bedrock displacement of $0.033 \mathrm{~m} \cdot \mathrm{d}^{-1}$. The best co-registration with GRAY was achieved in the northeastern scene with a mean bedrock displacement of $0.030 \mathrm{~m} \cdot \mathrm{d}^{-1}$. The largest bedrock displacements and therefore the worst co-registration were found in the southern scene with $0.097 \mathrm{~m} \cdot \mathrm{d}^{-1}$ using GAMMA and $0.120 \mathrm{~m} \cdot \mathrm{d}^{-1}$ using the GRAY method, respectively.

\section{Results}

\subsection{Velocity Map of Svalbard's Glaciers}

The fastest glacier in Svalbard at the time of the study was Basin-3 on Austfonna (\#16 in Figure 3). We captured the peak of its surge [14] only with the GAMMA software and found velocities up to $18.5 \mathrm{~m} \cdot \mathrm{d}^{-1}$.

The surges of Nathorstbreen (maximum speed: $\left.2.55 \mathrm{~m} \cdot \mathrm{d}^{-1}, \# 20\right)$, Sveabreen $\left(2.19 \mathrm{~m} \cdot \mathrm{d}^{-1}, \# 21\right)$ and Wahlenbergbreen $\left(1.51 \mathrm{~m} \cdot \mathrm{d}^{-1}, \# 22\right)$ are also captured. Other area-wide results were achieved for the outlets of Vestfonna, such as Nordre Franklinbreen $\left(0.72 \mathrm{~m} \cdot \mathrm{d}^{-1}\right.$, \#8), Idunbreen $\left(1.76 \mathrm{~m} \cdot \mathrm{d}^{-1}\right.$, \#9), Frazerbreen $\left(0.94 \mathrm{~m} \cdot \mathrm{d}^{-1}, \# 10\right)$, Aldousbreen $\left(1.06 \mathrm{~m} \cdot \mathrm{d}^{-1}, \# 11\right)$, Bodleybreen $\left(2.27 \mathrm{~m} \cdot \mathrm{d}^{-1}, \# 12\right)$, Rijpbreen $\left(1.83 \mathrm{~m} \cdot \mathrm{d}^{-1}\right.$, \#13) and of Austfonna, e.g., Duvebreen $\left(1.14 \mathrm{~m} \cdot \mathrm{d}^{-1}, \# 14\right)$ and Schweigaardbreen $\left(1.96 \mathrm{~m} \cdot \mathrm{d}^{-1}, \# 15\right)$. In the south of the archipelago Emil'janovbreen $\left(2.60 \mathrm{~m} \cdot \mathrm{d}^{-1}, \# 17\right)$, Oslokbreen $\left(1.35 \mathrm{~m} \cdot \mathrm{d}^{-1}, \# 18\right)$ and Austre Torellbreen $\left(1.20 \mathrm{~m} \cdot \mathrm{d}^{-1}, \# 19\right)$ are three fast flowing glaciers. One of the fastest non-surging glaciers is Kronebreen $\left(2.12 \mathrm{~m} \cdot \mathrm{d}^{-1}, \# 1\right)$ in NW-Svalbard. Kongsbreen $\left(1.95 \mathrm{~m} \cdot \mathrm{d}^{-1}\right.$, \#2) and Blomstrandbreen $\left(1.96 \mathrm{~m} \cdot \mathrm{d}^{-1}, \# 3\right)$ flow at a very similar rate. Other fast flowing glaciers in the northwest are Liliehøøkbreen $\left(1.33 \mathrm{~m} \cdot \mathrm{d}^{-1}, \# 4\right)$, Monacobreen $\left(2.13 \mathrm{~m} \cdot \mathrm{d}^{-1}, \# 5\right)$ and Aavatsmarkbreen $\left(1.40 \mathrm{~m} \cdot \mathrm{d}^{-1}\right.$, \#23). In the north, Nordbreen (\#7) flows at up to $0.71 \mathrm{~m} \cdot \mathrm{d}^{-1}$ and at the southern tip of Austfjorden, Mittag-Lefflerbreen (\#6) has a maximum speed of $0.70 \mathrm{~m} \cdot \mathrm{d}^{-1}$. 
In the following sections, we focus on the performance of the algorithms at several case study glaciers. We present surface velocity fields and speed profiles along the centerline (defined in a dynamical sense as the line of maximum surface speed) of the following glaciers: Nathorstbreen (5.2), Kronebreen (5.3), Kongsbreen (5.4) and Monacobreen (5.5).

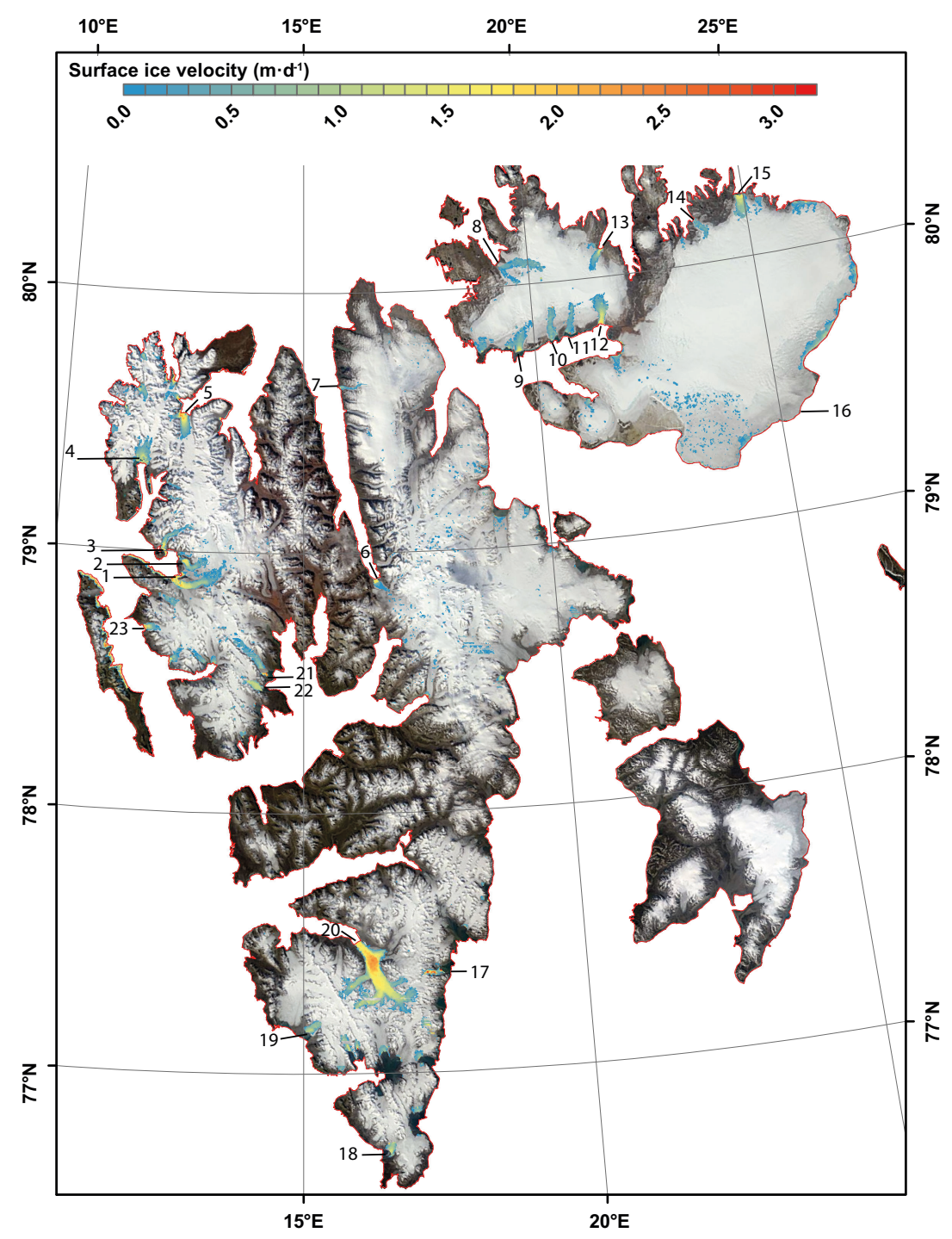

Figure 3. Surface speed of Svalbard glaciers processed with the GRAY method (fastest speed is quoted). \#1: Kronebreen $\left(2.12 \mathrm{~m} \cdot \mathrm{d}^{-1}\right)$; \#2: Kongsbreen $\left(1.95 \mathrm{~m} \cdot \mathrm{d}^{-1}\right)$; \#3: Blomstrandbreen $\left(1.96 \mathrm{~m} \cdot \mathrm{d}^{-1}\right)$; \#4: Liliehøøkbreen $\left(1.33 \mathrm{~m} \cdot \mathrm{d}^{-1}\right)$; \#5: Monacobreen $\left(2.13 \mathrm{~m} \cdot \mathrm{d}^{-1}\right)$; \#6: Mittag-Lefflerbreen $\left(0.70 \mathrm{~m} \cdot \mathrm{d}^{-1}\right)$; \#7: Nordbreen $\left(0.71 \mathrm{~m} \cdot \mathrm{d}^{-1}\right)$; \#8: Nordre Franklinbreen $\left(0.72 \mathrm{~m} \cdot \mathrm{d}^{-1}\right)$; \#9: Idunbreen $\left(1.76 \mathrm{~m} \cdot \mathrm{d}^{-1}\right)$; \#10: Frazerbreen $\left(0.94 \mathrm{~m} \cdot \mathrm{d}^{-1}\right)$; \#11: Aldousbreen $\left(1.06 \mathrm{~m} \cdot \mathrm{d}^{-1}\right)$; \#12: Bodleybreen $\left(2.27 \mathrm{~m} \cdot \mathrm{d}^{-1}\right)$; \#13: Rijpbreen $\left(1.83 \mathrm{~m} \cdot \mathrm{d}^{-1}\right)$; \#14: Duvebreen $\left(1.14 \mathrm{~m} \cdot \mathrm{d}^{-1}\right)$; \#15: Schweigaardbreen $\left(1.96 \mathrm{~m} \cdot \mathrm{d}^{-1}\right)$; \#16: Basin-3 (18.5 $\mathrm{m} \cdot \mathrm{d}^{-1}$, the peak of the surge could not be captured with GRAY); \#17: Emil'janovbreen; \#18: Oslokbreen $\left(1.35 \mathrm{~m} \cdot \mathrm{d}^{-1}\right)$; \#19: Austre Torellbreen $\left(1.20 \mathrm{~m} \cdot \mathrm{d}^{-1}\right)$; \#20: Nathorstbreen system $\left(2.55 \mathrm{~m} \cdot \mathrm{d}^{-1}\right)$; \#21: Sveabreen $\left(2.19 \mathrm{~m} \cdot \mathrm{d}^{-1}\right)$; \#22: Wahlenbergbreen $\left(1.51 \mathrm{~m} \cdot \mathrm{d}^{-1}\right)$; \#23: Aavatsmarkbreen $\left(1.40 \mathrm{~m} \cdot \mathrm{d}^{-1}\right)$. Dates of speed estimates are given in Figure 1 and Table 2. Background image: MODIS Terra RGB composite.

\subsection{Nathorstbreen}

Between 19 December 2012 and 12 January 2013 the glacier system still flowed at an accelerated rate of $1.70-1.80 \mathrm{~m} \cdot \mathrm{d}^{-1}$ at the calving front compared to before the surge. Maximum speed $\left(2.60-3.30 \mathrm{~m} \cdot \mathrm{d}^{-1}\right)$ 
was reached 10-15 $\mathrm{km}$ upstream of the front where the glacier spreads out from its constraining valley (Figure 4a). The speed continuously decreases farther upstream, but, $30 \mathrm{~km}$ upglacier from the front, speeds of greater than $1 \mathrm{~m} \cdot \mathrm{d}^{-1}$ are still measured (Figure $4 \mathrm{~b}$ ).

\section{Nathorstbreen}
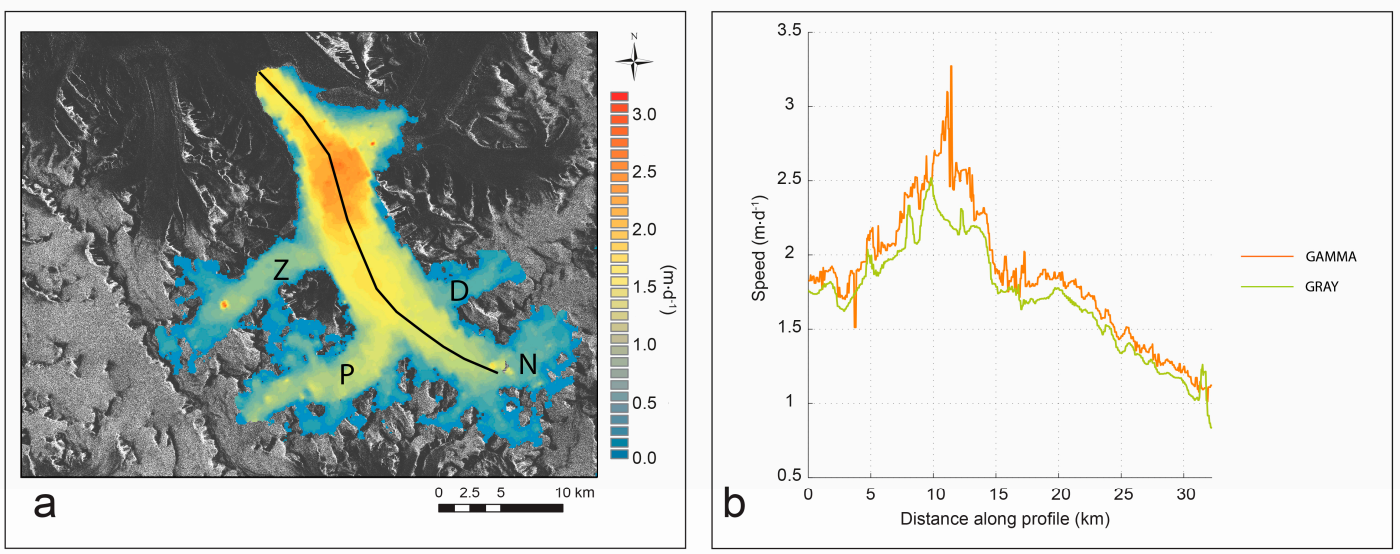

Figure 4. (a) Surface speed of the Nathorstbreen system (\#20 in Figure 3) in S-Spitsbergen consisting of Nathorstbreen (N), Dobrowolskibreen (D), Polakbreen (P) and Zawatzkibreen (Z) (19 December 2012-12 January 2013; WF; GRAY); and (b) speed profile along the centerline of Nathorstbreen (orange: GAMMA; green: GRAY).

The profiles in Figure $4 \mathrm{~b}$ show that the surface speed derived by GAMMA is generally higher than the GRAY derived speeds, especially at the speed maximum where GAMMA measures $>3.27 \mathrm{~m} \cdot \mathrm{d}^{-1}$ while GRAY is around $2.55 \mathrm{~m} \cdot \mathrm{d}^{-1}$.

\subsection{Kronebreen}

For Kronebreen, we found a maximum speed at the calving front of $\sim 2.00 \mathrm{~m} \cdot \mathrm{d}^{-1}$ between 1 January and 25 January 2013 (Figure 5). Speed diminishes quickly as one moves upglacier from the calving front and by $5 \mathrm{~km}$ inland it stabilizes at around $0.80-0.90 \mathrm{~m} \cdot \mathrm{d}^{-1}$. The length of the speed profile which could be extracted from both methods is $\sim 11 \mathrm{~km}$; upglacier of this distance, the speed gets too low and erroneous matching results dominate. It is noteworthy that the profile derived from GRAY shows consistently higher speeds than GAMMA along the whole profile, with a mean difference of $0.13 \pm 0.04 \mathrm{~m} \cdot \mathrm{d}^{-1}$. The maximum difference is $0.24 \mathrm{~m} \cdot \mathrm{d}^{-1}$.

\section{Kronebreen}
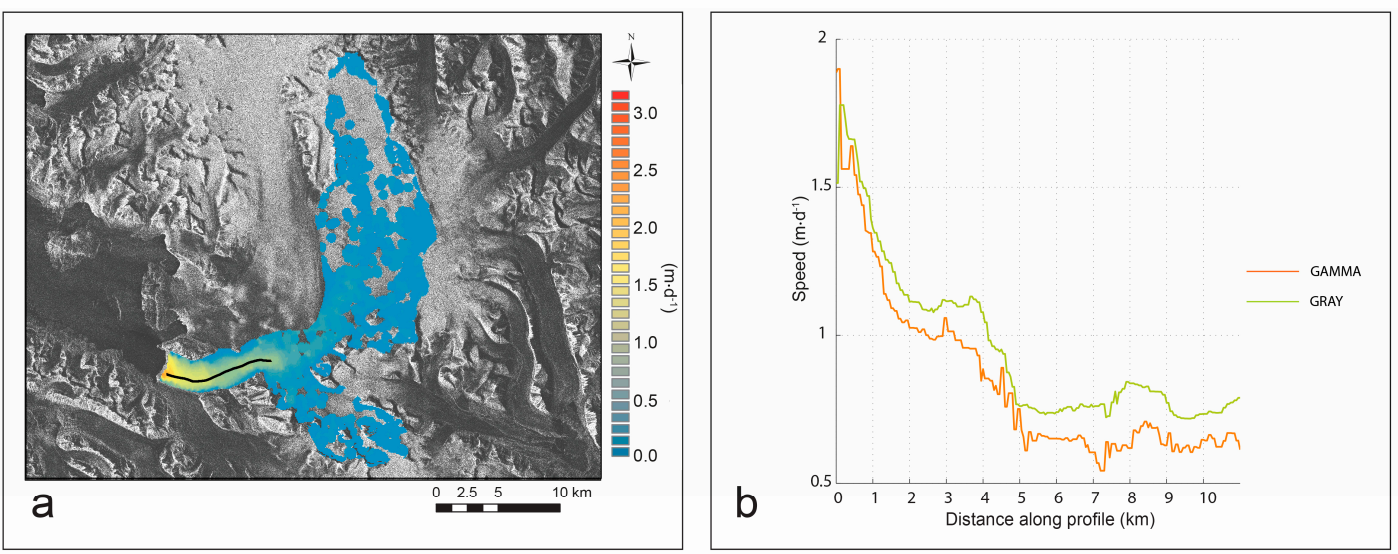

Figure 5. (a) Surface speed of Kronebreen (\#1 in Figure 3) in NW-Spitsbergen (1-25 January 2013; WF; GRAY); and (b) speed profile along the centerline of Kronebreen (orange: GAMMA; green: GRAY). 


\subsection{Kongsbreen}

Kongsbreen is fed by the icefield Isachsenfonna and divides into two branches (Figure 6a). The northern branch is fast flowing with a maximum speed of $1.95 \mathrm{~m} \cdot \mathrm{d}^{-1}$ measured by GRAY at the calving front. While both algorithms show similar results in the fast flowing part up to $4.5 \mathrm{~km}$ from the calving front, GRAY speed is greater along the upglacier end of the profile. The mean difference is $0.09 \mathrm{~m} \cdot \mathrm{d}^{-1}$ with a standard deviation of $0.10 \mathrm{~m} \cdot \mathrm{d}^{-1}$.

\section{Kongsbreen}
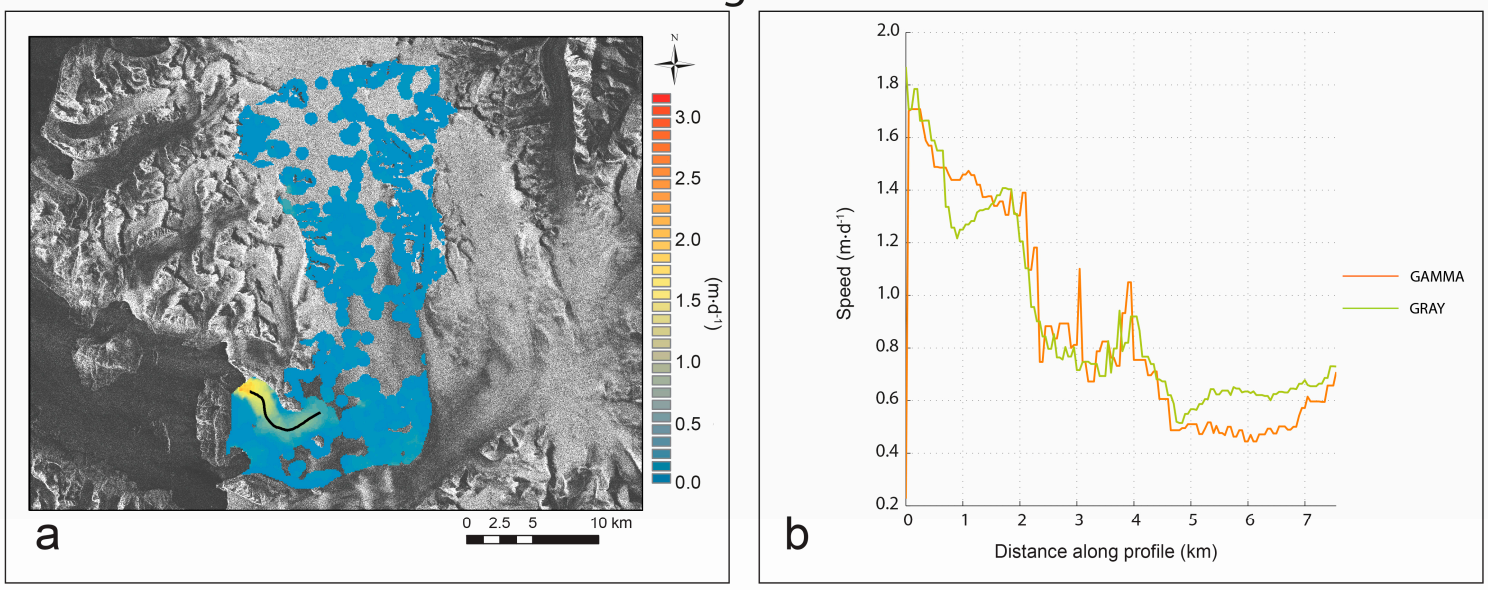

Figure 6. (a) Surface speed of the Kongsbreen (\#2 in Figure 3) in NW-Spitsbergen (1-25 January 2013; WF; GRAY); and (b) speed profile along the centerline of Kongsbreen (orange: GAMMA; green: GRAY).

\subsection{Monacobreen}

Monacobreen is a $40 \mathrm{~km}$ long tidewater glacier and also fed by Isachsenfonna (Figure 7). Speed at the calving front between 1 January and 25 January 2013 was up to $2.1 \mathrm{~m} \cdot \mathrm{d}^{-1}$, with a continuous decrease to $0.3 \mathrm{~m} \cdot \mathrm{d}^{-1} 8 \mathrm{~km}$ further inland. The profiles show very good agreement between the GAMMA and the GRAY results, with a mean difference of $0.006 \mathrm{~m} \cdot \mathrm{d}^{-1} \pm 0.046 \mathrm{~m} \cdot \mathrm{d}^{-1}$ and a maximum difference of $0.201 \mathrm{~m} \cdot \mathrm{d}^{-1}$.

\section{Monacobreen}
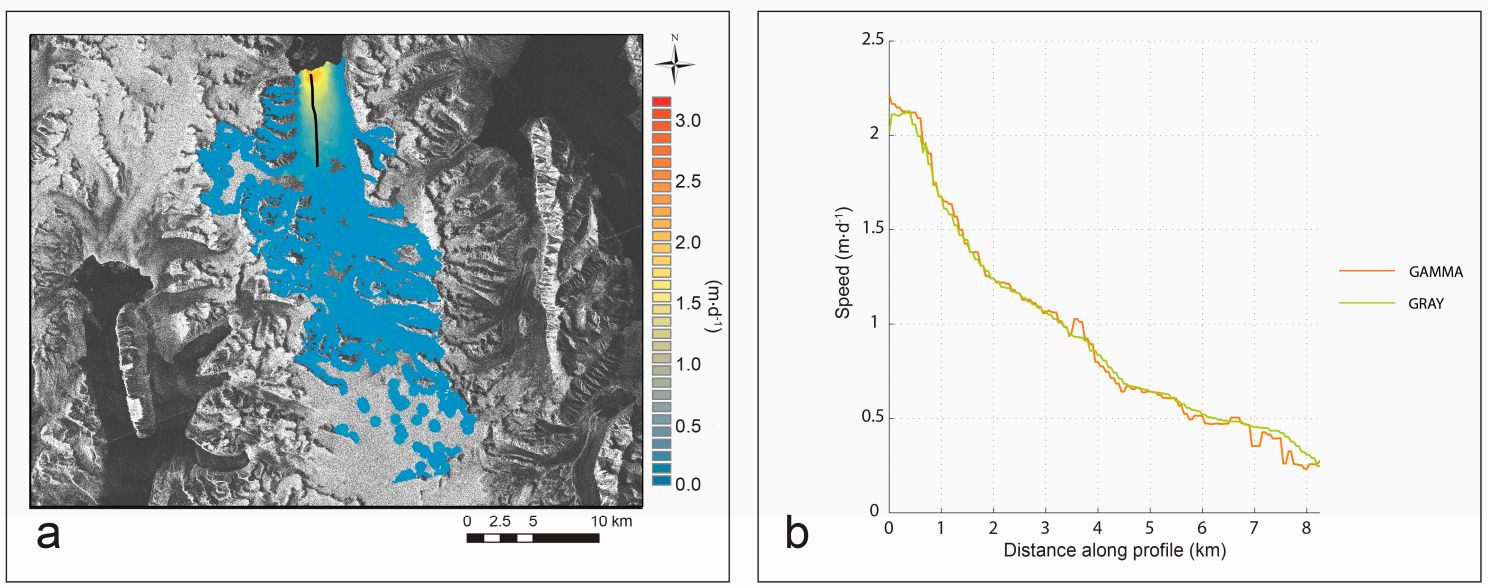

Figure 7. (a) Surface speed of the Monacobreen (\#5 in Figure 3) in N-Spitsbergen (1-25 January 2013; WF; GRAY); and (b) speed profile along the centerline of Monacobreen (orange: GAMMA; green: GRAY). 


\subsection{Other Results}

Besides the four selected glaciers described in detail above, we compared velocity profiles on an additional 51 glaciers. When subtracting calculated GRAY speeds along the profiles from GAMMA speeds, we find a bimodal distribution of the mean difference (Figure 8).

In sixteen cases, the mean difference is greater than zero, meaning that the mean speed derived by GAMMA is smaller than that by GRAY. In 32 cases the mean speed in GAMMA is larger than in GRAY, and in seven cases equal to GRAY. We speculate that the inaccuracies mainly come from the co-registration process (see Section 5.7). For the glacier in the northeastern scene, azimuth streaks could also be the reason for differences. The manual filtering procedure should instead have a minimum influence on the mean difference in speed as the same technique was used.

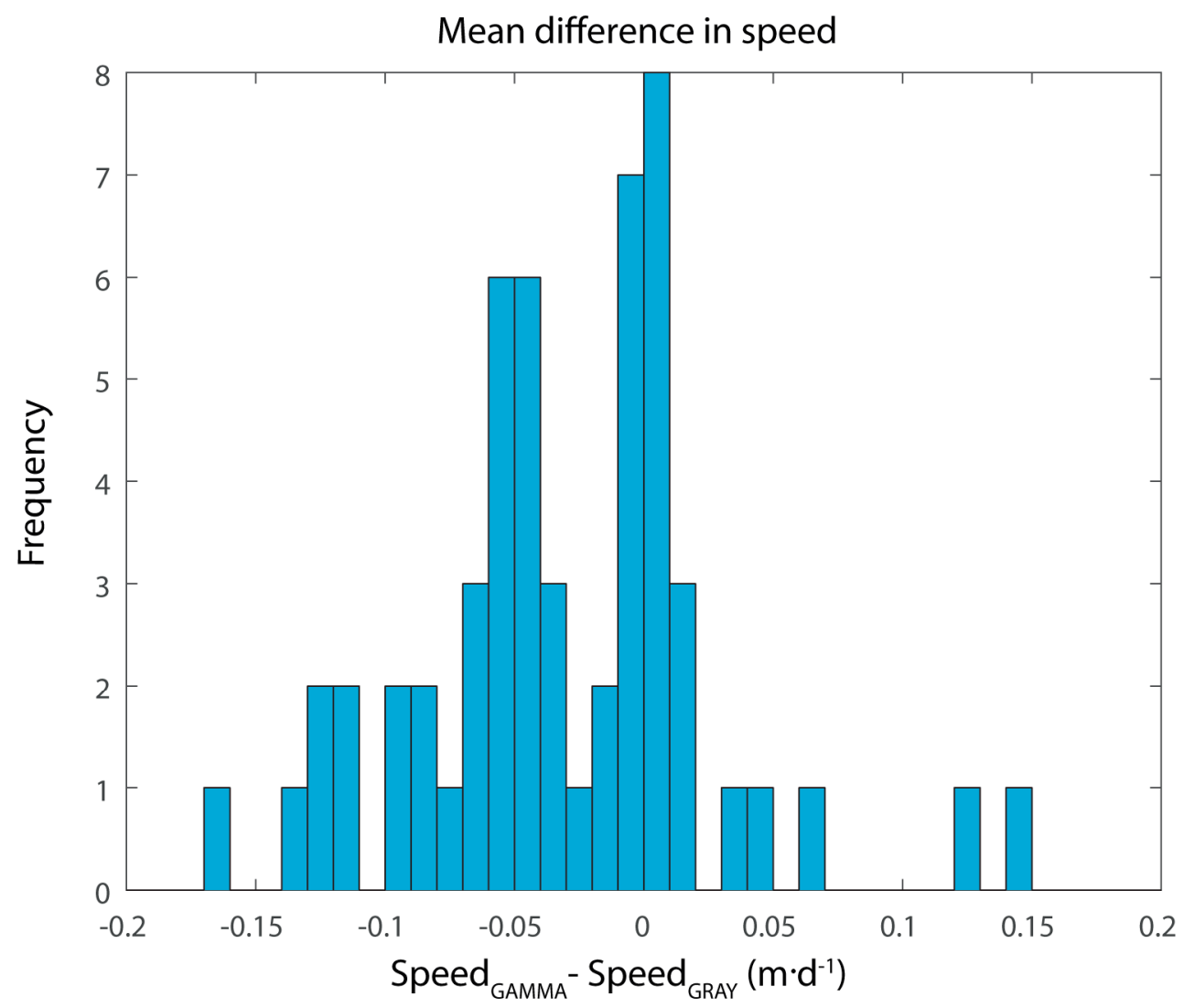

Figure 8. Frequency distribution of speed differences of 55 glaciers between GAMMA and GRAY.

\subsection{Comparison to Surface Speed from Different Radarsat-2 Modes}

We compare the performance of different RS-2 beam modes, namely the Ultrafine (UF), Wide Fine (WF) and Wide (W) modes at Kronebreen (Figure 9). We did not process the RS-2 Ultrafine (UF) and Wide $(W)$ data with the GRAY method due to restrictions in sharing these RS-2 data between the two groups. The RS-2 UF data were acquired on 3 January 2013 and 20 February 2013 and processed only using GAMMA. The velocity map has a $50 \mathrm{~m}$ pixel resolution and appears smooth, although we find mismatches and gaps in the map, probably due to the long time interval of 48 days (two repetition cycles) between the acquisitions (Figure 9a). The RS-2 W data of 25 December 2012 and 18 January 2013, processed with the GAMMA software, provide velocity estimates at $100 \mathrm{~m}$ resolution. Overall this is the roughest velocity field with the lowest quality (Figure 9b). We find mismatches regularly, especially outside the fast flowing part of the glacier. The RS-2 WF speed map based on the data acquired on 1 January 2013 and 25 January 2013 and processed with GAMMA are smoother and we do not find mismatches in the lower part of the glacier (Figure 9c). The same dataset processed 
with GRAY is even smoother as all mismatches are manually filtered by visual inspection and the gaps are interpolated (Figure 9d).
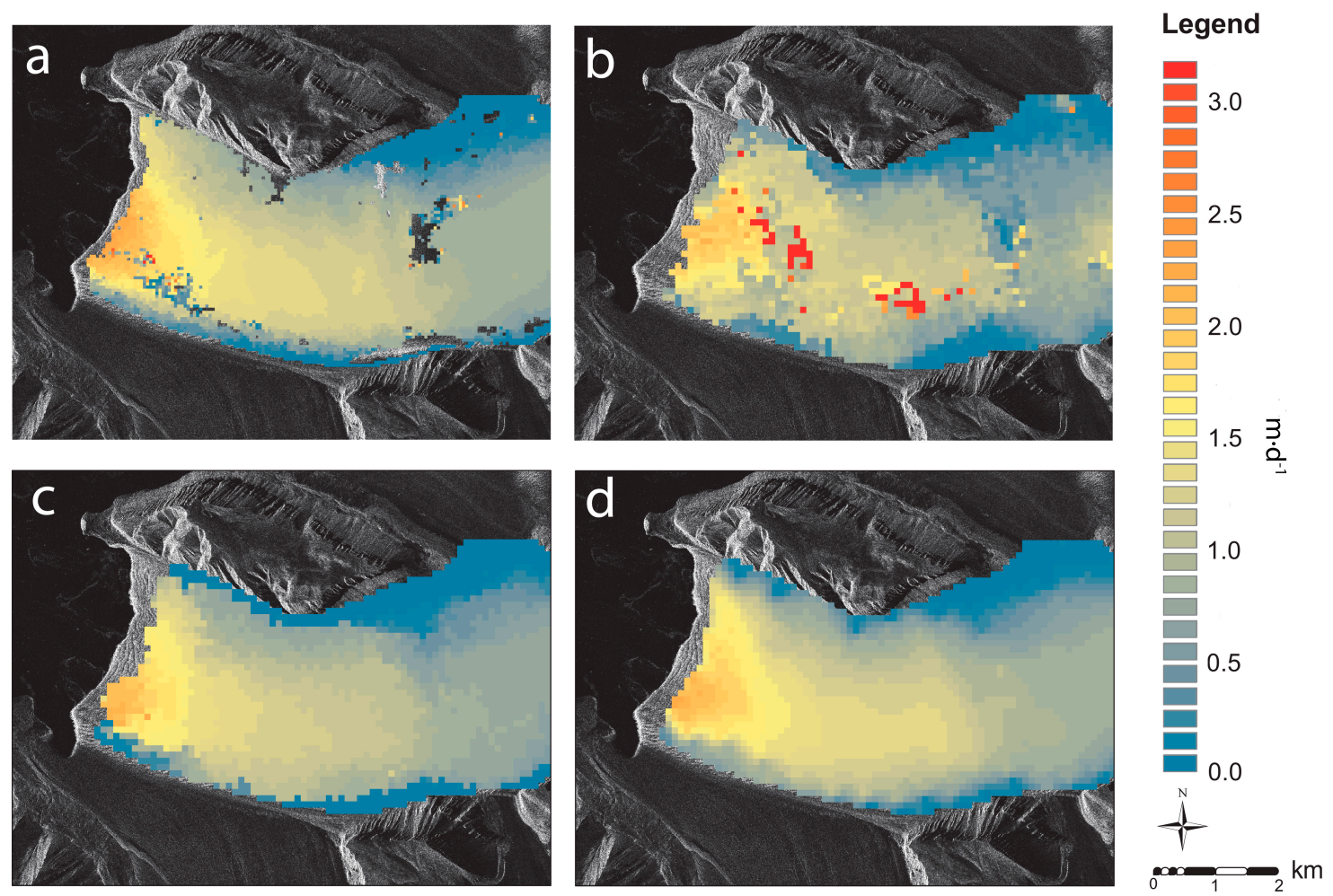

Figure 9. Surface speed of Kronebreen based on: (a) RS-2 UF data (3 January 2013-20 February 2013) processed with GAMMA; (b) RS-2 W data (25 December 2012-18 January 2013) processed with GAMMA; (c) RS-2 WF data (1 January 2013-25 January 2013) processed with GAMMA; and (d) RS-2 WF data (1 January 2013-25 January 2013) processed with GRAY.

We now compare the velocities based on RS-2 WF data to those based on the high resolution RS-2 UF data and medium resolution RS-2 W data. The RS-2 WF data were acquired on 1 January 2013 and 25 January 2013, and the RS-2 UF data on 3 January 2013 and 20 February 2013 (two repetition cycles). For the comparison we overlaid a $1 \mathrm{~km}$ grid of points on the velocity maps of Kronebreen. We then extracted the speed values from both velocity maps at these points and compared them to each other (Figure 10). The best fit with an $R^{2}=0.95$ and a linear fit of displacements $\mathrm{d}_{\mathrm{WF}, \text { GAMMA }}=0.94 \mathrm{~d}_{\mathrm{UF}}$, GAMMA was found between the GAMMA WF data and RS-2 UF (Figure 10a). GRAY WF performed slightly worse with an $\mathrm{R}^{2}=0.92$ and $\mathrm{d}_{\mathrm{WF}}$, GRAY $=1.01 \mathrm{~d}_{\mathrm{UF}}$, GAMMA (Figure 10b). Comparing the GAMMA WF data to GRAY WF, we calculate an $\mathrm{R}^{2}=0.95$ and a linear fit of $\mathrm{d}_{\mathrm{WF}, \text { GAMMA }}=0.91 \mathrm{~d}_{\mathrm{WF}, \text { GRAY }}$ (Figure 10c).

We also compared velocity estimates based on RS-2 W data between 25 December 2012 and 18 January 2013 to the RS-2 UF and WF data. We found a linear fit of $d_{W}$, GAMMA $=0.96 d_{\text {UF, GAMMA }}$ with an $\mathrm{R}^{2}$ of 0.77 and therefore worse fit than with the RS-2 WF data (Figure 10d). Additionally, we found that the comparison between GAMMA $W$ data and GRAY WF data shows similar values: $\mathrm{d}_{\mathrm{W}, \text { GAMMA }}=0.94 \mathrm{~d}_{\mathrm{WF}, \text { GRAY }}$ and $\mathrm{R}^{2}=0.77$. The fit between GAMMA $\mathrm{W}$ and GAMMA WF is as follows: $\mathrm{d}_{\mathrm{W}, \text { GAMMA }}=1.02 \mathrm{~d}_{\mathrm{WF}, \text { GAMMA }}$ and $\mathrm{R}^{2}=0.73$. 


\section{Speed comparisons}
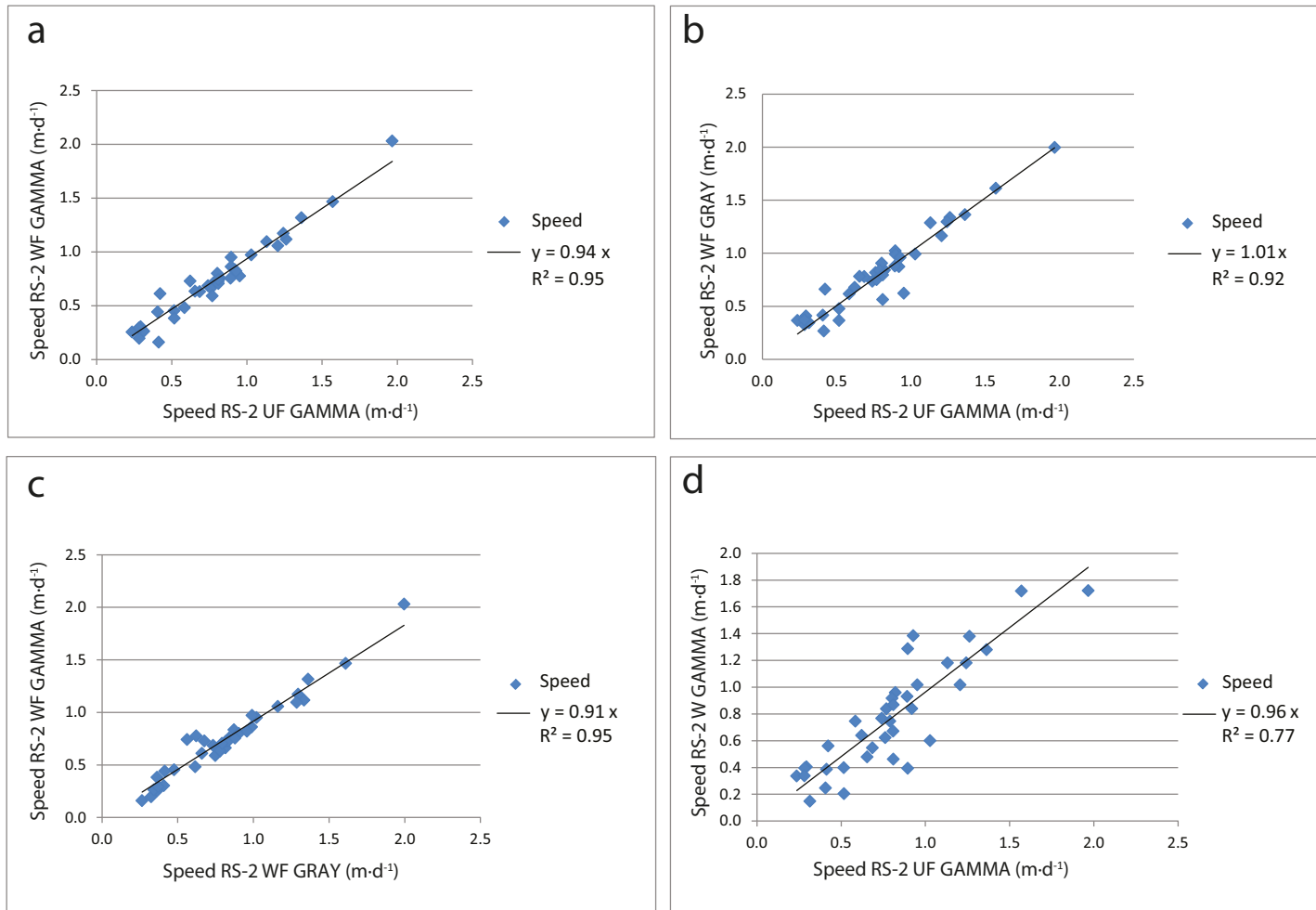

Figure 10. Validation of glacier speed on Kronebreen: Speed extracted from SAR maps on a $1 \mathrm{~km}$ point grid: (a) RS-2 UF GAMMA vs. RS-2 WF GAMMA; (b) RS-2 UF GAMMA vs. RS-2 WF GRAY; (c) RS-2 WF GRAY vs. RS-2 WF GAMMA; and (d) RS-2 UF GAMMA vs. RS-2 W GAMMA.

\section{Discussion}

The first area wide glacier surface velocity map of Svalbard provides good results for the major fast flowing glaciers on the archipelago.

Nevertheless SAR offset tracking was not capable of detecting small movements resulting in gaps in the surface velocity map where glaciers are flowing slowly. This is mainly because surface features and speckle patterns change rapidly in the maritime environment of Svalbard. In dryer regions such as the Canadian arctic, more favourable conditions also allow the detection of small displacements [6-8].

Moreover, although we applied various matching windows with the GRAY method to calculate displacements of Basin-3, this algorithm was not able to provide good matches. This is likely because the surface features changed too much (e.g., opening and widening of large crevasses) as the RS-2 data were acquired during the peak of the surge [14].

The second main glaciological feature on the archipelago is the surge of the Nathorstbreen system. In 2009, Dobrowolskibreen started to surge, and in 2010 the whole Nathorstbreen system consisting of Nathorstbreen (N), Dobrowolskibreen (D), Polakbreen (P) and Zawatzkibreen (Z) followed [20]. Sund et al. [20] found maximum velocities of $25 \mathrm{~m} \cdot \mathrm{d}^{-1}$ during the initiation of the Nathorstbreen glacier system surge. Three years later, the glacier still flows at an accelerated rate with a maximum velocity of about $3 \mathrm{~m} \cdot \mathrm{d}^{-1}$. This study also confirms that Kronebreen and the northern branch of Kongsbreen are among the fastest flowing tidewater glaciers in Svalbard as previously reported by Schellenberger et al. [19].

Monacobreen surged between 1991 and 1998 with its peak in 1993 [17]. Speed at the time of the peak was around $2.2 \mathrm{~m} \cdot \mathrm{d}^{-1}$ some $5 \mathrm{~km}$ upglacier from the front [17], meaning that current speeds are almost as high as during that peak. The velocity during its quiescent phase was calculated to be up to $3.0 \mathrm{~m} \cdot$ year $^{-1}$ [32]. We do not interpret the present fast flow of Monacobreen as a surge as 
the characteristic advance is missing. Instead, it seems to be continuously fast flowing, similar to Kronebreen and Kongsbreen, as seen from unpublished RS-2 Wide Mode data. It is outside of the scope of this paper to investigate further if this finding points to a change in subglacial regime for this glacier, and potential reasons and processes involved in this change.

The southeastern scene and central scene are obviously badly co-registered by GAMMA on their western sides, as seen from high bedrock displacements. We found displacements up to $11 \mathrm{~m}$ per repetition cycle (24 days). Possible reasons for the inaccurate co-registration are the existence of ocean water, glaciers and surface melt between the acquisitions. These are areas where points for a correct co-registration are unavailable. This leads to problems, as the fitted polynomial interpolation of the co-registration is very sensitive, especially over data voids and at data margins (i.e., at the coast where most fast-flowing glacier sections are situated). There, strong polynomial undulations can be caused by relatively small offsets in the co-registration measurements. Furthermore, slow moving parts of the glacier are less easy to detect as outliers in the co-registration process, meaning that they could be included in the fit and thus influence the co-registration offset. In contrast, co-registration measurements over fast-flowing glacier parts will be detected as outliers in the co-registration fit and subsequently eliminated. In future work, it might be useful to involve glacier and coastline masks to reduce such problems.

Comparisons between velocity maps based on RS-2 data at different spatial resolutions revealed the superiority of high and very high resolution data compared to medium resolution data. These observations are in line with comparisons of RS-2 UF and RS-2 W data to GPS data, which clearly show that the higher the original resolution of the SAR intensity data, the higher the quality of the speed maps [18].

\section{Conclusions}

Overall, this study has shown that both algorithms tested provide an efficient and effective means of monitoring glacier dynamics in Svalbard. The best results are found when estimating the surface speed of fast flowing glaciers. However, there can be large gaps in the velocity map where glaciers are flowing slowly, which is likely partly due to the absence of trackable crevasses on such glacier sections, amongst other reasons. We conclude that it is generally more difficult to derive glacier velocities using offset tracking methods in Svalbard than other glacier regions, such as the Canadian Arctic. This is largely because of regional climatic differences, where the maritime climate of Svalbard, with rain events possible year round, can frequently result in changes to surface properties even within a single 24-day Radarsat-2 repetition cycle in winter. New sensors such as Sentinel-1A may thus be better suited for long-term monitoring of Svalbard glaciers due to their shorter repeat cycle (currently 12 days for Sentinel-1A, or 6 days when combined with Sentinel-1B data). Shorter repeat cycles should greatly reduce the probability of significant glacier change between image acquisitions for the maritime conditions on Svalbard. In addition, under such reduced repeat times, phase coherence might occur, at least in winter, and thus allow for true speckle tracking compared to the amplitude-only matching which is possible for RS-2 data over Svalbard.

The second goal of this study was to compare two offset and speckle tracking algorithms, namely the GAMMA Remote Sensing Software and the GRAY method. Generally, both methods worked well and had fairly comparable results as seen from in-depth comparisons of surface velocities of four glaciers. The GRAY velocity fields are smoother due to the interpolation of the matches to a $100 \mathrm{~m}$ pixel resolution in ArcGIS. It should also be noted that the glacier speed estimation is very sensitive to the co-registration process, with the differences between the two algorithms mainly coming from differences in this step. Co-registration was especially problematic in GAMMA for scenes, which contain large regions of ocean water and glaciers, i.e. little stable ground.

A comparison of GRAY WF and GAMMA WF with higher resolution RS-2 UF data also showed that both algorithms perform equally well. The resolution and quality of the velocity maps based on RS-2 UF data are better as the resolution of the original intensity data is higher. When comparing the 
RS-2 W data to RS-2 UF, the superiority of the WF data over the W mode is revealed due to the higher pixel resolution of the intensity data.

Acknowledgments: Thomas Schellenberger was funded by the Research Council of Norway (RASTAR, grant No. 2080139) and the Norwegian Space Centre as part of European Space Agency's PRODEX program (C4000106033). Andreas Kääb has also received funding from the European Research Council under the European Union's Seventh Framework Programme (FP/2007-2013)/ERC grant agreement No. 320816, and the ESA project Glaciers_cci (4000109873/14/I-NB). Radarsat-2 Wide Fine data were provided by CSA under SOAR-EDU proposal 5118. RADARSAT Wide and Fine Mode data were provided by NSC/KSAT under the Norwegian-Canadian Radarsat agreements 2007-2015. We also thank Chris Nuth for providing the compiled ASTER GDEM of Svalbard. ASTER GDEM is a product of NASA and METI. MODIS data, courtesy of the NASA EOSDIS Land Processes Distributed Active Archive Center (LP DAAC), USGS/Earth Resources Observation and Science (EROS) Center, Sioux Falls, South Dakota. We are grateful to F. Raspini and the anonymous reviewers for their detailed comments on the manuscript that certainly helped to improve the quality of our publication.

Author Contributions: Thomas Schellenberger, Wesley Van Wychen, Luke Copland and Andreas Kääb designed the study. Thomas Schellenberger processed the data with the GAMMA software and wrote the manuscript. Wesley Van Wychen processed the data with the GRAY method and contributed to the manuscript. Luke Copland and Andreas Kääb provided the data and edited the manuscript. Laurence Gray provided the MATLAB code and commented on the manuscript.

Conflicts of Interest: The authors declare no conflict of interest.

\section{Abbreviations}

The following abbreviations are used in this manuscript:

$\begin{array}{ll}\text { DEM } & \text { Digital Elevation Model } \\ \text { F } & \text { Fine mode } \\ \text { MN } & \text { mid-north } \\ \text { MW } & \text { mid-west } \\ \text { NE } & \text { northeast } \\ \text { ENE } & \text { east-northeast } \\ \text { NW } & \text { northwest } \\ \text { RS-2 } & \text { Radarsat-2 } \\ \text { S } & \text { south } \\ \text { SAR } & \text { Synthetic Aperture Radar } \\ \text { SE } & \text { southeast } \\ \text { UF } & \text { Ultra-Fine mode } \\ \text { W } & \text { Wide mode } \\ \text { WF } & \text { Wide Fine mode }\end{array}$

\section{References}

1. Rignot, E.; Mouginot, J.; Scheuchl, B. Ice flow of the Antarctic Ice Sheet. Science 2011, 333, $1427-1430$. [CrossRef] [PubMed]

2. Joughin, I.; Smith, B.E.; Howat, I.M.; Scambos, T.; Moon, T. Greenland flow variability from ice-sheet-wide velocity mapping. J. Glaciol. 2010, 56, 415-430. [CrossRef]

3. Nagler, T.; Rott, H.; Hetzenecker, M.; Wuite, J.; Potin, P. The Sentinel-1 Mission: New Opportunities for Ice Sheet Observations. Remote Sens. 2015, 7, 9371-9389. [CrossRef]

4. Burgess, E.W.; Forster, R.R.; Larsen, C.F. Flow velocities of Alaskan glaciers. Nat. Commun. 2013, 4. [CrossRef] [PubMed]

5. Melkonian, A.K.; Willis, M.J.; Pritchard, M.E. Satellite-derived volume loss rates and glacier speeds for the Juneau Icefield, Alaska. J. Glaciol. 2014, 60, 743-760. [CrossRef]

6. Van Wychen, W.; Copland, L.; Gray, L.; Burgess, D.; Danielson, B.; Sharp, M. Spatial and temporal variation of ice motion and ice flux from Devon Ice Cap, Nunavut, Canada. J. Glaciol. 2012, 58, 657-664. [CrossRef]

7. Van Wychen, W.; Burgess, D.O.; Gray, L.; Copland, L.; Sharp, M.; Dowdeswell, J.A.; Benham, T.J. Glacier velocities and dynamic ice discharge from the Queen Elizabeth Islands, Nunavut, Canada. Geophys. Res. Lett. 2014, 41, 484-490. [CrossRef]

8. Van Wychen, W.; Copland, L.; Burgess, D.O.; Gray, L.; Schaffer, N. Glacier velocities and dynamic discharge from the ice masses of Baffin Island and Bylot Island, Nunavut, Canada. Can. J. Earth Sci. 2015, 52, 980-989. [CrossRef] 
9. Floricioiu, D.; Eineder, M.; Rott, H.; Nagler, T. Velocities of Major Outlet Glaciers of the Patagonia Icefield Observed by TerraSAR-X. In Proceedings of the IEEE International Geoscience and Remote Sensing Symposium (IGARSS), Boston, MA, USA, 7-11 July 2008; pp. 347-350.

10. Melkonian, A.K.; Willis, M.J.; Pritchard, M.E.; Rivera, A.; Bown, F.; Bernstein, S.A. Satellite-derived volume loss rates and glacier speeds for the Cordillera Darwin Icefield, Chile. Cryosphere 2013, 7, 823-839. [CrossRef]

11. Mouginot, J.; Rignot, E. Ice motion of the Patagonian Icefields of South America: 1984-2014. Geophys. Res. Lett. 2015, 42, 1441-1449. [CrossRef]

12. Blaszczyk, M.; Jania, J.A.; Hagen, J.O. Tidewater glaciers of Svalbard: Recent changes and estimates of calving fluxes. Pol. Polar Res. 2009, 30, 85-142.

13. Dowdeswell, J.A.; Unwin, B.; Nuttall, A.M.; Wingham, D.J. Velocity structure, flow instability and mass flux on a large Arctic ice cap from satellite radar interferometry. Earth Planet. Sci. Lett. 1999, 167, 131-140. [CrossRef]

14. Dunse, T.; Schellenberger, T.; Hagen, J.O.; Kääb, A.; Schuler, T.V.; Reijmer, C.H. Glacier-surge mechanisms promoted by a hydro-thermodynamic feedback to summer melt. Cryosphere 2015, 9, 197-215. [CrossRef]

15. Kääb, A.; Lefauconnier, B.; Melvold, K. Flow field of Kronebreen, Svalbard, using repeated Landsat 7 and ASTER data. Ann. Glaciol. 2005, 42, 7-13. [CrossRef]

16. Luckman, A.; Benn, D.I.; Cottier, F.; Bevan, S.; Nilsen, F.; Inall, M. Calving rates at tidewater glaciers vary strongly with ocean temperature. Nat. Commun. 2015, 6, 8566. [CrossRef] [PubMed]

17. Luckman, A.; Murray, T.; Strozzi, T. Surface flow evolution throughout a glacier surge measured by satellite radar interferometry. Geophys. Res. Lett. 2002, 29. [CrossRef]

18. Pohjola, V.A.; Christoffersen, P.; Kolondra, L.; Moore, J.C.; Pettersson, R.; Schäfer, M.; Strozzi, T.; Reijmer, C.H. Spatial distribution and change in the surface ice-velocity field of Vestfonna ice cap, Nordaustlandet, Svalbard, 1995-2010 using geodetic and satellite interferometry data. Geogr. Ann. Ser. A Phys. Geogr. 2011, 93, 323-335. [CrossRef]

19. Schellenberger, T.; Dunse, T.; Kääb, A.; Kohler, J.; Reijmer, C.H. Surface speed and frontal ablation of Kronebreen and Kongsbreen, NW Svalbard, from SAR offset tracking. Cryosphere 2015, 9, 2339-2355. [CrossRef]

20. Sund, M.; Lauknes, T.R.; Eiken, T. Surge dynamics in the Nathorstbreen glacier system, Svalbard. Cryosphere 2014, 8, 623-638. [CrossRef]

21. Wangensteen, B.; Weydahl, D.J.; Hagen, J.O. Mapping glacier velocities on Svalbard using ERS tandem DInSAR data. Norsk Geogr. Tidsskr. Nor. J. Geogr. 2005, 59, 276-285. [CrossRef]

22. Joughin, I.; Smith, B.E.; Abdalati, W. Glaciological advances made with interferometric synthetic aperture radar. J. Glaciol. 2010, 56, 1026-1042. [CrossRef]

23. Schubert, A.; Faes, A.; Kääb, A.; Meier, E. Glacier surface velocity estimation using repeat TerraSAR-X images: Wavelet- vs. correlation-based image matching. ISPRS J. Photogramm. Remote Sens. 2013, 82, 49-62. [CrossRef]

24. Paul, F.; Bolch, T.; Kääb, A.; Nagler, T.; Nuth, C.; Scharrer, K.; Shepherd, A.; Strozzi, T.; Ticconi, F.; Bhambri, R.; et al. The glaciers climate change initiative: Methods for creating glacier area, elevation change and velocity products. Remote Sens. Environ. 2015, 162, 408-426. [CrossRef]

25. Strozzi, T.; Luckman, A.; Murray, T.; Wegmüller, U.; Werner, C.L. Glacier motion estimation using SAR offset-tracking procedures. IEEE Trans. Geosci. Remote Sens. 2002, 40, 2384-2391. [CrossRef]

26. Short, N.H.; Gray, L. Glacier dynamics in the Canadian High Arctic from RADARSAT-1 speckle tracking. Can. J. Remote Sens. 2005, 31, 225-239. [CrossRef]

27. Hagen, J.O.; Liestøl, O.; Roland, E.; Jørgensen, T. Glacier Atlas of Svalbard and Jan Mayen; Norsk Polarinstitutt: Oslo, Norway, 1993.

28. Raspini, F.; Ciampalini, A.; Del Conte, S.; Lombardi, L.; Nocentini, M.; Gigli, G.; Ferretti, A.; Casagli, N. Exploitation of Amplitude and Phase of Satellite SAR Images for Landslide Mapping: The Case of Montescaglioso (South Italy). Remote Sens. 2015, 7, 14576-14596. [CrossRef]

29. Paradella, W.R.; Ferretti, A.; Mura, J.C.; Colombo, D.; Gama, F.F.; Tamburini, A.; Santos, A.R.; Novali, F.; Galo, M.; Camargo, P.O.; et al. Mapping surface deformation in open pit iron mines of Carajás Province (Amazon Region) using an integrated SAR analysis. Eng. Geol. 2015, 193, 61-78. [CrossRef]

30. MDA. Radarsat-2 Product Description; MDA: Richmond, BC, Canada, 2015.

31. Nuth, C.; Kohler, J.; König, M.; von Deschwanden, A.; Hagen, J.O.; Kääb, A.; Moholdt, G.; Pettersson, R. Decadal changes from a multi-temporal glacier inventory of Svalbard. Cryosphere 2013, 7, 1603-1621. [CrossRef] 
32. Murray, T.; Strozzi, T.; Luckman, A.; Jiskoot, H.; Christakos, P. Is there a single surge mechanism? Contrasts in dynamics between glacier surges in Svalbard and other regions. J. Geophys. Res. Solid Earth 2003, 108. [CrossRef]

33. Gray, A.L.; Short, N.; Mattar, K.E.; Jezek, K.C. Velocities and flux of the Filchner ice shelf and its tributaries determined from speckle tracking interferometry. Can. J. Remote Sens. 2001, 27, 193-206. [CrossRef]

34. Waechter, A.; Copland, L.; Herdes, E. Modern glacier velocities across the Icefield Ranges, St Elias Mountains, and variability at selected glaciers from 1959 to 2012. J. Glaciol. 2015, 61, 624-634. [CrossRef]

35. Rosen, P.A.; Hensley, S.; Joughin, I.R.; Fuk, K.L.; Madsen, S.N.; Rodriguez, E.; Goldstein, R.M. Synthetic aperture radar interferometry. Proc. IEEE 2000, 88, 333-382. [CrossRef]

36. den Ouden, M.A.G.; Reijmer, C.H.; Pohjola, V.; van de Wal, R.S.W.; Oerlemans, J.; Boot, W. Stand-alone single-frequency GPS ice velocity observations on Nordenskiöldbreen, Svalbard. Cryosphere 2010, 4, 593-604. [CrossRef]

(C) 2016 by the authors; licensee MDPI, Basel, Switzerland. This article is an open access article distributed under the terms and conditions of the Creative Commons Attribution (CC-BY) license (http://creativecommons.org/licenses/by/4.0/). 